\title{
Metabolic endotoxaemia in childhood obesity
}

\author{
Madhusudhan C. Varma', Christine M. Kusminski', Sahar Azharian'1, Luisa Gilardini², Sudhesh Kumar', \\ Cecilia Invitti ${ }^{2}$ and Philip G. McTernan ${ }^{*}$
}

\begin{abstract}
Background: Childhood obesity is associated with chronic low-grade inflammation considered as a precursor to metabolic disease; however, the underlying mechanisms for this remain unclear. Studies in adults have implicated gut derived gram-negative bacterial fragments known as lipopolysaccharide or endotoxin, activating the inflammatory response, whilst the importance in childhood obesity is unclear. The aim of this research is to understand the relationship between circulating endotoxin in childhood obesity, and its' association with inflammatory and cardiovascular (CV) injury biomarkers.

Methods: Fasted blood was obtained from children with varying degrees of obesity (age: $13.9 \pm 2.3 \mathrm{Yr}$; BMl: $\left.35.1 \pm 5.2 \mathrm{Kg} / \mathrm{m}^{2} ; n=60\right)$. Multiplex CVD biomarker immunoassays were used to determine systemic levels of inflammatory and vascular injury biomarkers, such as tumour necrosis factor-a (TNF-a), interleukin (IL-) 1ß, 6, 8 and 10, plasminogen activator inhibitor-1 (PAI-1), soluble intercellular adhesion molecule type-1 (sICAM-1), matrix metalloproteinase-9 (MMP-9), myeloperoxidase (MPO) and vascular endothelial growth factor (VEGF) as well as endotoxin levels.
\end{abstract}

Results: Endotoxin levels demonstrated a significant and positive correlation with the markers for inflammation, vascular injury and atherogenesis (TNF-a: $r^{2}=0.077, p<0.05$; PAI-1: $r^{2}=0.215, p<0.01$; sICAM-1: $r^{2}=0.159, p<0.01$; MMP-9: $r^{2}=0.159, p<0.01 ;$ MPO: $r^{2}=0.07, p<0.05 ;$ VEGF: $\left.r^{2}=0.161, p<0.01\right)$. Males demonstrated significantly higher circulating endotoxin than females (Males: $9.63 \pm 5.34 \mathrm{EU} / \mathrm{ml} ; p=0.004$; Females: $5.56 \pm 4.06 \mathrm{EU} / \mathrm{ml} ; n=60$ ) in these BMI and age-matched cohorts.

Conclusion: The present study demonstrates for the first time a significant association between circulating endotoxin and biomarkers of metabolic risk in children as young as 11 years. Thus, endotoxin-mediated sub-clinical inflammation during childhood obesity may be a key contributor to T2DM and CVD development later in life.

Keywords: Endotoxin, Childhood obesity, Cardiovascular injury markers, Insulin resistance

\section{Background}

Environmental, physical and nutritional factors appear critical in determining lifetime disease risk profile for cardiovascular disease (CVD), which is a leading cause of mortality worldwide [1-3]. CVD development in later life shows an increased risk when the condition is preceded by prior chronic inflammatory conditions [4-9]. Therefore the clinical value of determining the factors that induce an inflammatory response in early life

\footnotetext{
* Correspondence: p.g.mcternan@warwick.ac.uk

${ }^{1}$ Division of Biomedical sciences, Warwick Medical School, University of Warwick, UHCW Trust, Clifford Bridge Road, Walsgrave, Coventry CV2 2DX, UK Full list of author information is available at the end of the article
}

appears important to address. Clearly childhood obesity per se has a significant impact on disease risk, inflammation and CVD, however, adipose tissue (AT) may be an early contributor to metabolic dysfunction through prior systemic insults, which initiate an inflammatory response $[7,8,10-14]$.

One cellular mechanism for an increased inflammatory response may arise through activation of the innate immune system as observed in human AT $[14,15]$. Previous studies have shown that increased activation of the innate immune pathway may arise through excess circulating gut derived bacteria, known as lipopolysaccharide 
(LPS) or endotoxin; which represents fragments from the outer cell wall membrane of gram-negative bacteria [14-16]. In human AT, it appears endotoxin has an immediate impact on the innate immune pathway, acting via key receptors known as the toll like receptors (TLRs), which recognise antigens such as the LPS component, to initiate an acute phase response to infection $[8,14]$. Stimulation of the TLRs leads to intracellular activation of $\mathrm{NF \kappa B}$, a key transcription factor in the inflammatory cascade that regulates the transcription of numerous pro-inflammatory adipocytokines [14, 15]. Therefore whilst in vitro, endotoxin may act as a mediator of inflammation through activation of $\mathrm{NF}_{\kappa} \mathrm{B}$, leading to a rapid response, in an in vivo situation that may be further exacerbated by an increasing fat mass, such as in obesity [17-21].

Clinical studies have also implicated gut derived endotoxin as a direct 'primary mediator' to activate the inflammatory state, contributing to metabolic disease, with current cross sectional data showing elevated systemic endotoxin levels in conditions of obesity, coronary artery disease, type 2 diabetes mellitus and fatty liver disease $[8,14-16]$, which is reduced with weight change [17, 21]. Studies in adults has also shown circulating endotoxin to be positively associated with waist, waist-hip-ratio, insulin levels, inflammatory cytokines as well as lipids, including total cholesterol, triglycerides, LDL-cholesterol and negatively associated with HDL-cholesterol [8, 17-21]. Recent studies in obese children and adolescents has demonstrated that systemic inflammatory cytokines such as plasminogen activator inhibitor-1 (PAI-1) and C-reactive protein (CRP) are elevated, along with vascular injury and atherogenesis markers, such as vascular cell adhesion molecule-1 (VCAM-1) and intercellular adhesion molecule type-1 (ICAM-1) [21-24]. Whether such pathogenic biomarkers directly correlate with systemic endotoxin concentrations in obese children and adolescents is undetermined. We have examined and concluded that bactrial endotoxin is a potential biomarker of sub-clinical inflammation and early CVD risk in childhood obesity.

\section{Methods}

\section{Subjects}

A total of 60 (unless stated otherwise in the figure legend) obese children and adolescents with varying degrees of obesity (BMI: mean $\pm(\mathrm{SD}) 35.1 \pm 5.2 \mathrm{~kg} / \mathrm{m}^{2}$; age: $13.9 \pm 2.3$ years) were recruited among those referred for weight loss intervention to the obesity centre of the Istituto Auxologico Italiano. All subjects were above the age and sex adjusted 97th BMI percentile, which defines obesity according to the Italian BMI charts [25] and had an age range of 8-18 years. The Ethics Committee of the Italian Institute approved this study and informed consent was obtained from all subjects and their parents. All subjects underwent an oral glucose tolerance test $(1.75 \mathrm{~g} / \mathrm{Kg}$, up to a maximum of $75 \mathrm{~g}$ glucose in $250 \mathrm{ml}$ of water) following an overnight fast. Plasma samples were drawn at baseline, after $30 \mathrm{~min}$ and $120 \mathrm{~min}$, for determination of plasma glucose and insulin concentration. Categorisation of glucose tolerance status was made using the World Health Organisation criteria [20]. The impaired fasting glucose was defined by fasting glucose levels $\geq 5.6 \mathrm{mmol} / \mathrm{l}$ [26]. Blood samples were drawn for measurement of endotoxin, adiponectin and, markers of inflammation and CVD. Blood pressure measurements were taken as previously described [11]. Insulin resistance was measured by HOMA-IR (fasting insulin $\mathrm{x}$ fasting glucose/22.5) [27].

\section{Biochemical measurements}

Serum endotoxin was assayed using a Chromogenic Limulus Amebocyte Lysate (LAL) test, which is a quantitative test for gram-negative bacterial endotoxin (Cambrex, New Jersey, USA) endotoxin-free vials were utilised throughout. Gram-negative bacterial endotoxin catalyzes the activation of a pro-enzyme in the Limulus Amebocyte Lysate (LAL). The initial rate of activation is directly determined by the concentration of endotoxin. The activated enzyme catalyzes the splitting of p-nitroaniline (pNA) from the colourless substrate Ac-lle-Glu-Ala-Arg-pNA. The pNA released was measured photometrically at 405$410 \mathrm{~nm}$ following termination of the reaction. The correlation between the absorbance and the endotoxin concentration is linear in the $0.1-1.0 \mathrm{EU} / \mathrm{mL}$ range. Intra-assay CV $3 \cdot 9 \pm 0 \cdot 46$, inter-assay CV $9 \cdot 6 \pm 0 \cdot 75$. For the purposes of these studies all samples were run in duplicate within the same plate, therefore no inter-assay variability was observed in this study. To assess recovery of endotoxin within the assay, previous studies have utilised known concentrations of recombinant endotoxin (0.25 and $1.00 \mathrm{EU} / \mathrm{mL}$ ) were added to diluted, pooled plasma to determine whether the expected concentration correlated closely with the actual observed value and whether there were any variations due to reaction with plasma contents [14]. Lyophilized endotoxin (E. coli origin) was used to generate a standard curve with the Chromogenic LAL test kit from Cambrex and produced a corresponding curve in accordance with the manufacturer's instructions. In plasma, the recovery of spiked endotoxin was $82.0 \pm 3.3 \%$ efficient, similar recovery data were noted for serum. Plate to plate variability within the same experiment was $7.4 \pm$ $0.9 \%$, these findings were similar to those observed from assessment by Cambrex [14].

A multiplexed CVD Panel 1 immunoassay (Linco Research, Missouri, USA) was utilised to examine the circulating concentrations of the following inflammatory and CVD risk biomarkers: TNF- $\alpha$, PAI-1 (tPAI-1, total) 
Table 1 Clinical and biochemical characteristics for obese, BMI and age-matched male $(n=24)$ and female $(n=36)$ subjects

\begin{tabular}{|c|c|c|c|}
\hline \multirow{2}{*}{$\begin{array}{l}\text { Clinical and biochemical } \\
\text { characteristics }\end{array}$} & \multirow{2}{*}{$\begin{array}{l}\text { Male } \\
\text { Subjects }( \pm S D)\end{array}$} & \multirow{2}{*}{$\begin{array}{l}\text { Female } \\
\text { Subjects }( \pm S D)\end{array}$} & \multirow[t]{2}{*}{$p$ value } \\
\hline & & & \\
\hline Age (yrs) & $14 \pm 3$ & $14 \pm 2$ & - \\
\hline BMI $\left(\mathrm{kg} / \mathrm{m}^{2}\right)$ & $34.0 \pm 5.1$ & $35.6 \pm 5.3$ & - \\
\hline Fasting Glucose (mmol/l) & $4.4 \pm 0.3$ & $4.5 \pm 0.5$ & N/S \\
\hline $2 \mathrm{~h}$ glucose, $\mathrm{mmol} / \mathrm{l}$ & $6.0 \pm 1.0$ & $5.7 \pm 1.0$ & $N / S$ \\
\hline HOMA-IR & $2.6 \pm 1.2$ & $3.3 \pm 2.1$ & N/S \\
\hline Endotoxin (EU/ml) & $10.1 \pm 5.4$ & $5.3 \pm 3.7$ & $p<0.01^{* *}$ \\
\hline CRP $(\mu \mathrm{g} / \mathrm{ml})$ & $7.5 \pm 8.3$ & $9.0 \pm 7.5$ & $N / S$ \\
\hline TNF-a (pg/ml) & $5.0 \pm 2.5$ & $5.9 \pm 5.8$ & $N / S$ \\
\hline PAl-1 (ng/ml) & $27.0 \pm 10.7$ & $26.0 \pm 15.7$ & $N / S$ \\
\hline sICAM-1 (ng/ml) & $110.4 \pm 37.4$ & $103.1 \pm 47.9$ & N/S \\
\hline Systolic BP (mmHg) & $121.0 \pm 10.8$ & $119.1 \pm 8.5$ & N/S \\
\hline Diastolic BP (mmHg) & $74.0 \pm 11.2$ & $72.7 \pm 8.5$ & $N / S$ \\
\hline
\end{tabular}

Data are expressed as mean \pm SD. significant differences in data between male and female subjects are highlighted $\left(P\right.$-Value $\left.{ }^{* *}, p<0.001\right)$

CRP, soluble intercellular adhesion molecule type-1 (sICAM-1), soluble vascular cell adhesion molecule-1 (sVCAM-1), MMP-9, MPO, VEGF and soluble endothelial selectin (sE-Selectin). The CVD Panel 1 immunoassay had a sensitivity of $16-50,000 \mathrm{pg} / \mathrm{ml}$ for MMP-9, MPO and PAI-1 and further, a sensitivity of 80$250,000 \mathrm{pg} / \mathrm{ml}$ for sICAM-1, sVCAM-1 and sE-Selectin; with an intra- and interassay CV of 4.5-12.3\% and 8.5$16.3 \%$, respectively. Plasma glucose was measured using an automated glucose analyser (Roche Diagnostics, Mannheim, Germany). Serum insulin levels were measured by a chemiluminescent assay (DPC, Los Angeles,
USA) with a sensitivity of $14.3 \mathrm{pmol} / \mathrm{l}$ and intra- and interassay CV of 3.7 and $6.7 \%$, respectively.

\section{Statistical analysis}

All analyses were performed using statistical software (SPSS, version 14; Woking, UK). Variables that were not normally distributed were log transformed. Differences between groups were calculated using a Student's $t$-test for independent samples. A Pearsons' correlation analysis was used to analyse bivariate relationships between endotoxin and the various markers of inflammation and vascular injury. Data were expressed as mean \pm SD. A $p$-value $<0.05$ was considered statistically significant.

\section{Results}

\section{Effect of gender on biomarkers of inflammation}

From this cohort, biochemical analysis was performed on 24 male subjects and 36 female subjects with matching BMI and age. Clinical and biochemical characteristics of male and female obese subjects are provided in Table 1. No significant gender differences were observed in HOMA-IR, blood pressure or several markers of inflammation and $\mathrm{CV}$ injury.

\section{Correlation of endotoxin with biomarkers of inflammation and CVD in childhood \& adolescent obesity}

In this study circulating endotoxin concentrations significantly and positively correlated with TNF- $\alpha(p<0.05$, $\left.\mathrm{r}^{2}=0.077\right)$ and MCP-1 $\left(p<0.01, \mathrm{r}^{2}=0.178\right)($ Fig. 1a, b). However, no significant correlation was noted between circulating endotoxin levels and CRP ( $p=$ N.S, $\left.\mathrm{r}^{2}=-0.069\right)$.

With regards to CVD risk markers, circulating endotoxin concentrations further correlated with several
A

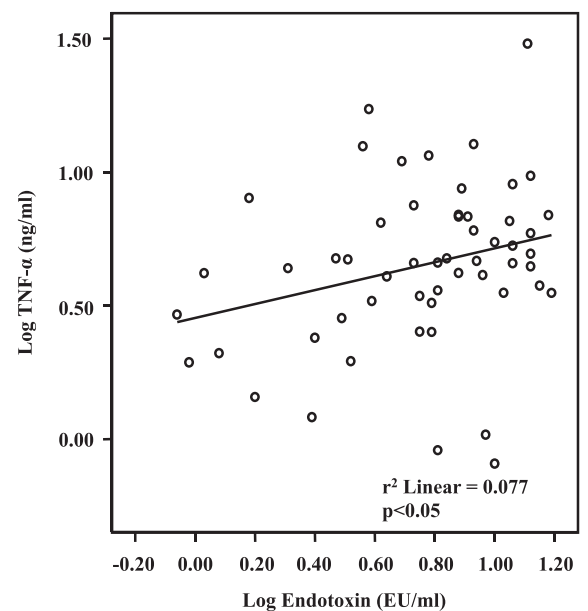

B

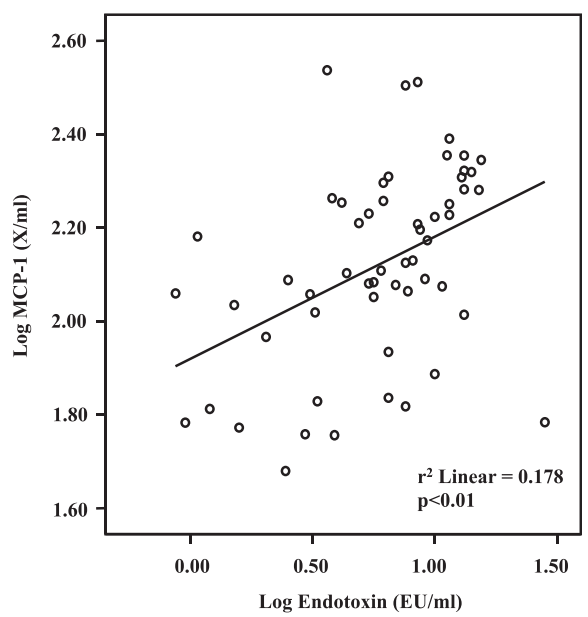

Fig. 1 Correlation between log endotoxin (EU/ml) levels and the inflammatory markers: (a) log TNF-a pg/ml $(p<0.05)(\mathbf{b}) \log \mathrm{MCP}-1 \mathrm{ng} / \mathrm{ml}$ $(p<0.01)$, in BMl and age-matched children and adolescents 


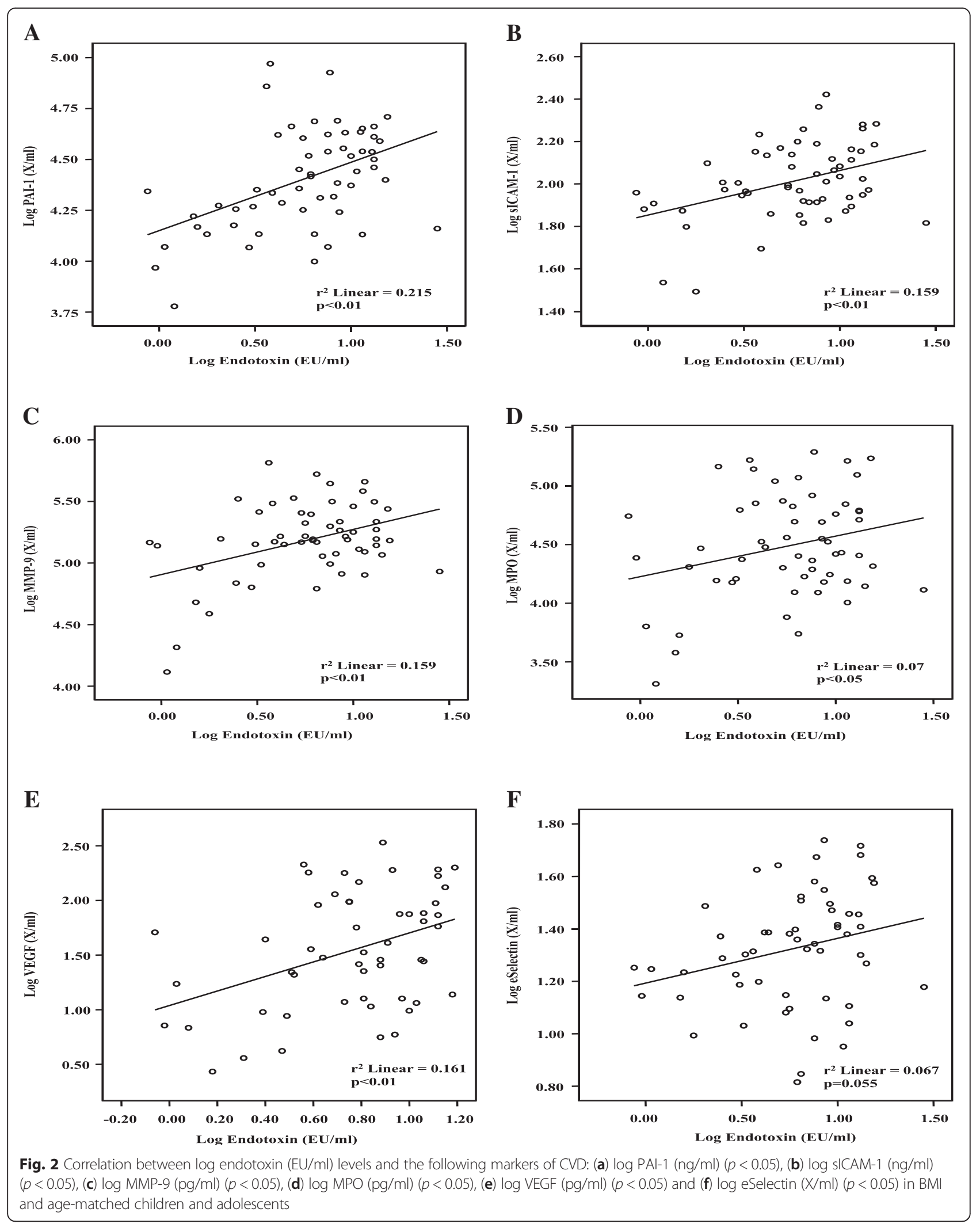


parameters of atherogenesis and vascular injury; these included PAI-1 $\left(p<0.01, \mathrm{r}^{2}=0.215\right)$, sICAM-1 $(p<0.01$, $\left.\mathrm{r}^{2}=0.159\right)$, MMP-9 $\left(p<0.01, \mathrm{r}^{2}=0.159\right)$, MPO $(p<0.05$, $\left.\mathrm{r}^{2}=0.07\right)$ and VEGF $\left(p<0.01, \mathrm{r}^{2}=0.161\right)$ (Fig. $\left.2 \mathrm{a}-\mathrm{f}\right)$. No significant correlation was observed between endotoxin and sE-Selectin levels $\left(p=0.055, \mathrm{r}^{2}=0.067\right)$ or sVCAM-1 levels $\left(p=\mathrm{N} . \mathrm{S}, \mathrm{r}^{2}=0.054\right)$.

Additional analysis of serum concentration data revealed that circulating endotoxin levels positively correlated with systolic blood pressure $\left(p<0.05 ; \mathrm{r}^{2}=0.155 ; n=37\right)$ (Fig. 3a) and diastolic blood pressure $\left(p<0.05 ; \mathrm{r}^{2}=0.083 ; n=51\right)$ (Fig. 3b). Endotoxin was higher in males than females as a direct comparison (Fig. 4).

\section{Discussion}

These current studies highlight that in childhood obesity circulating endotoxin is significantly correlated with proinflammatory markers, TNF- $\alpha$, MCP- 1 , as well as biomarkers of atherogenesis and vascular injury including PAI-1, sICAM-1, MMP-9 and MPO, VEGF. Furthermore, data analysis also determined that circulating endotoxin levels are positively correlated with both systolic and diastolic blood pressure in children with obesity. Taken together these findings also indicate that the presence of metabolic endotoxinaemia, which appears to occur in childhood, correlates with pathogenic proinflammatory factors in a similar manner to that noted in adults with metabolic disease [14, 15, 17, 21, 22]. These studies also appear to suggest that the raised endotoxin levels in childhood are coupled to a noted high disease risk profile and blood pressure, which together ultimately could lead to an earlier life progression of CVD. Endotoxin may also account for, in part, the continual pro-inflammatory state experienced in obese children [28-31].
These studies also observed for the first time a noted significant rise in circulating endotoxin in boys compared with girls. Whilst this was not the aim of the study these findings appear consistent with gender-specific effects noted in adults; maintained across several ethnicities [19]. Prior studies in adults suggest a higher endotoxin-induced pro-inflammatory cytokine release in men than women, although this study in children did not identify this gender specific aspect [32,33]. Such a disparity in endotoxin-induced pro-inflammatory cytokine release between the children and adults with obesity may arise, in part, due to the difference in exposure time to endotoxin; which in obese adults may give rise to long-term damaging inflammatory change leading to T2DM [26, 34, 35].

These studies also suggest that changes in inflammation, vascular dysfunction, and blood pressure in childhood obesity may arise beyond the known impact of the cardiometabolic lipid profile [29, 30, 32, 37, 38]. A key mediator to increase disease risk arise from circulating commensal bacterial endotoxin, derived from the gastrointestinal-tract eliciting a pro-inflammatory response in prior childhood and adolescent obesity studies [36, 39, 40]. Additionally, adult studies highlight that diets high in fat and or processed meat appear to raise endotoxin levels further, whilst dairy products and other food combinations may reduce endotoxin levels and inflammation [18, 4143]. As such further future insight into examining the impact of diet on endotoxin levels in children with obesity may highlight important interventions to reduce the longterm health risk [14, 40, 44-46].

Several risk factors in childhood have been proposed to predict the later development of CVD including obesity, hypertension and endothelial dysfunction promoting atherogenesis and thrombosis [47-50]. In our cohort of
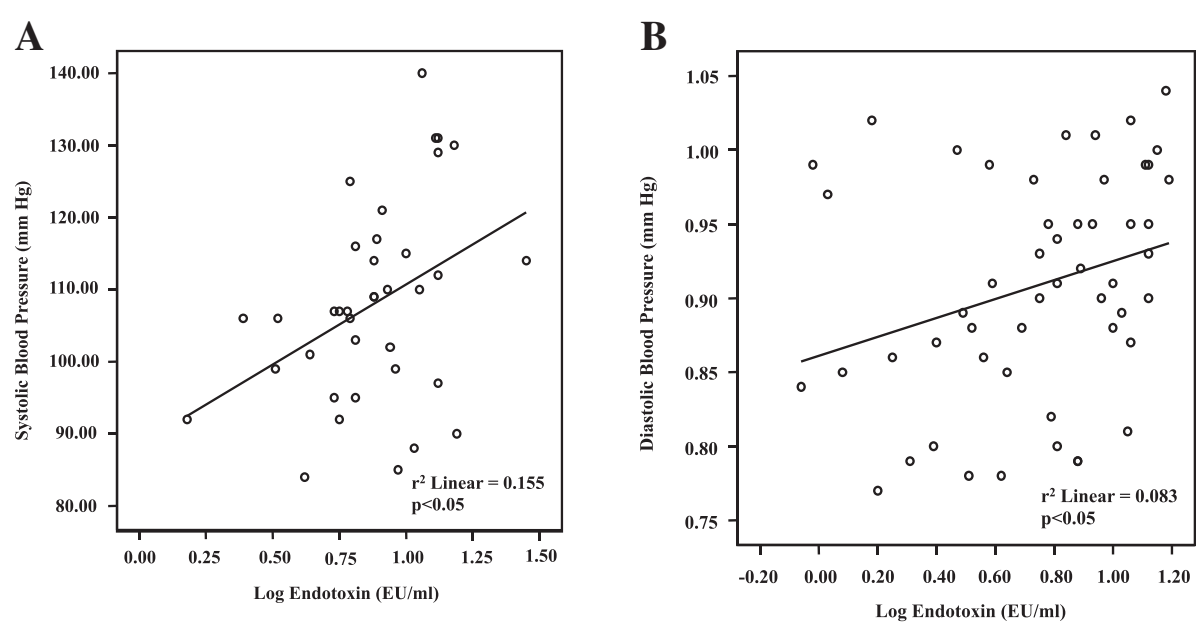

Fig. 3 Correlation between log endotoxin (EU/ml) levels and (a) systolic blood pressure ( $\mathrm{mm} \mathrm{Hg})(n=37)$ and (b) diastolic blood pressure ( $\mathrm{mm} \mathrm{Hg})$ $(n=51)$ in BMl and age-matched children and adolescents 


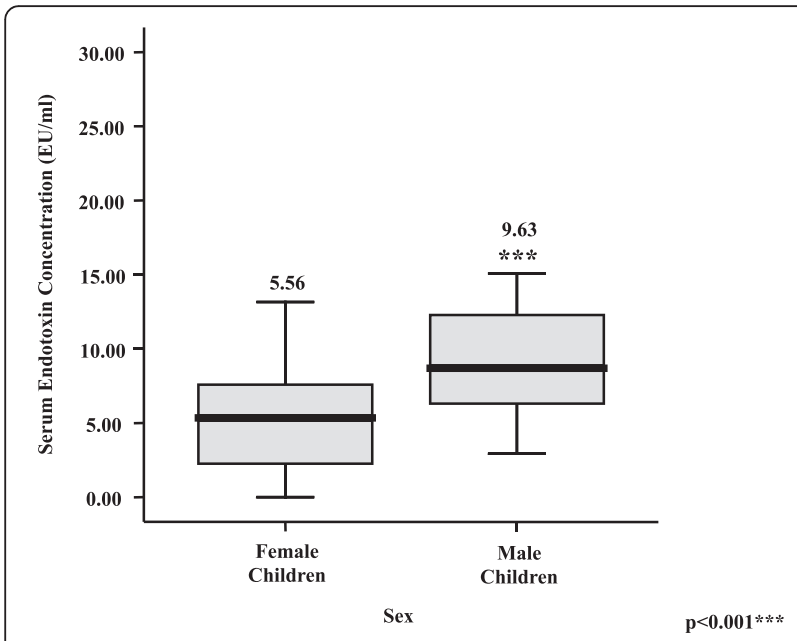

Fig. 4 Comparison of the mean relative endotoxin serum concentrations $(E U / \mathrm{ml}) \pm S E M$ in male and female BMI and age-matched children and adolescents

obese children and adolescents, several biomarkers of vascular injury and endothelial dysfunction, including PAI-1, sICAM-1, MMP-9, MPO and VEGF, were significantly and positively correlated with circulating endotoxin concentrations. The observed pro-inflammatory biomarker risk profile in the obese children appears to be similar to both what has been identified in adults with CVD as well as studies comparing obese and lean children [50,51].

Hypertension has been identified as a key risk factor for atherogenesis and vascular injury, and this study noted a positive association between endotoxin with systolic and diastolic blood pressure. As such a diet that raises endotoxin levels would appear to also increase blood pressure. However this is a cross-sectional study, which therefore cannot determine a causal relationship, although previous studies have demonstrated that mice fed a continuous endotoxin bolus, exhibited a subsequent increase in vascular dysfunction $[52,53]$. This is consistent with the concept that an endotoxin-induced inflammatory response in childhood obesity, may consequently contribute to an accelerated risk of CVD in later life. Furthermore the noted correlations between circulating endotoxin and biomarkers of endothelial dysfunction, in this childhood obesity study, could also promote a cluster of these pro-atherogenic factors contributing to accelerated atherosclerosis, arterial stiffness and CVD in later life [37, 54-57].

This study had some limitations, namely: the crosssectional design which did not allow causal determinations and a limited sample size indicating modest correlations. Further, the lack of gender-effects on the correlations between endotoxin and the pro-inflammatory factors may also be considered a reflection of the limited cohort size. Thus, future studies exploring further aspects of these observations in larger cohorts are warranted.

\section{Conclusion}

In summary, this study highlights the relationship between endotoxin and several inflammatory and CVD risk biomarkers, particularly as an early player in obesity-related inflammatory disorders during childhood and adolescence. Furthermore, even at an early age in the obese state, female subjects exhibited lower endotoxin levels than their male counterparts, suggesting a more favourable metabolic profile. This may manifest in later life as delayed CVD mortality and morbidity for females in contrast to males. Finally, among the inflammatory markers evaluated in this study, endotoxin may serve as a potential mediator of sub-clinical inflammation in childhood and adolescent obesity as noted in adult studies.

\section{Abbreviations \\ BMI: Body mass index; CRP: c-reactive protein; CV: Cardiovascular; CVD: Cardiovascular disease; HDL: High density lipoprotein; HOMA-IR: Homeostatic model assessment of insulin resistance; ICAM-1: Intercellular adhesion molecule type-1; IL: Interleukin; LDL: Low density lipoprotein; MCP-1: Monocyte chemoattractant protein-1; MMP-9: Matrix metalloproteinase-9; MPO: Myeloperoxidase; PAI-1: Plasminogen activator inhibitor - 1; sICAM-1: Soluble intercellular adhesion molecule type-1; sVCAM-1: Soluble vascular cell adhesion molecule-1; T2DM: Type 2 diabetes mellitus; TLR-4: Toll-like receptors; TNF-a: Tumour necrosis factor-a; VCAM-1: Vascular cell adhesion molecule type-1; VEGF: Vascular endothelial growth factor.}

\section{Competing interests \\ The authors declare they have no competing interests.}

\section{Authors' contributions}

MV, CK, SA conducted the experimental work for the clinical samples and data analysis as well as writing and revision of manuscript. Cl, LG undertook all work leading to ethical approval of the project, selection and recruitment of patients, taking the clinical history and blood sample collection as well as input into the design of the experiment and manuscript revision. SK inputted into the design, data interpretation and coordination of the study. PGM lead the experimental design, supported data analysis, data interpretation, in addition to writing the manuscript. All authors read and approved the final manuscript.

\section{Acknowledgements}

Madhusudhan Varma was funded by a British Medical Institute fellowship. The authors would also like to thank Coventry \& District Charitable Trust, the Rowlands Trust, and the Jarman Charitable Trust for their support of this research.

\section{Author details}

${ }^{1}$ Division of Biomedical sciences, Warwick Medical School, University of Warwick, UHCW Trust, Clifford Bridge Road, Walsgrave, Coventry CV2 2DX, UK. ²Department of Medical Sciences \& Rehabilitation, IRCCS Istituto Auxologico Italiano, Via Ariosto 13, 20145 Milan, Italy.

Received: 4 July 2015 Accepted: 19 January 2016

Published online: 27 January 2016

References

1. Reinikainen J, Laatikainen T, Karvanen J, Tolonen H. Lifetime cumulative risk factors predict cardiovascular disease mortality in a 50-year follow-up study in Finland. Int J Epidemiol. 2015;44(1):108-16.

2. Jankovic N, Geelen A, Streppel MT, de Groot LC, Kiefte-de Jong JC, Orfanos $P$, et al. WHO guidelines for a healthy diet and mortality from cardiovascular disease in European and American elderly: the CHANCES project. Am J Clin Nutr. 2015;102(4):745-56

3. Bartha JL, Fernández-Deudero A, Bugatto F, Fajardo-Exposito MA, GonzálezGonzález N, Hervías-Vivancos B. Inflammation and cardiovascular risk in women with preterm labor. J Womens Health. 2012;21(6):643-8. Epub 2012 Mar 8. 
4. Bonamy AK, Parikh NI, Cnattingius S, Ludvigsson JF, Ingelsson E. Birth characteristics and subsequent risks of maternal cardiovascular disease: effects of gestational age and fetal growth. Circulation. 2011;124(25):2839-46. Epub 2011 Nov 28.

5. John $\mathrm{H}$, Kitas $\mathrm{G}$. Inflammatory arthritis as a novel risk factor for cardiovascular disease. Eur J Intern Med. 2012;23(7):575-9.

6. Kranendonk ME, van Herwaarden JA, Stupkova T, de Jager W, Vink A, Moll FL, et al. Inflammatory characteristics of distinct abdominal adipose tissue depots relate differently to metabolic risk factors for cardiovascular disease: distinct fat depots and vascular risk factors. Atherosclerosis. 2015;239(2):419-27.

7. Olza J, Aguilera CM, Gil-Campos M, Leis R, Bueno G, Valle M, et al. Waist-toheight ratio, inflammation and CVD risk in obese children. Public Health Nutr. 2014;17(10):2378-85.

8. Eguchi K, Manabe I. Toll-like receptor, lipotoxicity and chronic nflammation: the pathological link between obesity and cardiometabolic disease. J Atheroscler Thromb. 2014;21(7):629-39.

9. Banerjee D, Biggs ML, Mercer L, Mukamal K, Kaplan R, Barzilay J, et al. Insulin resistance and risk of incident heart failure: Cardiovascular Health Study. Circ Heart Fail. 2013;6(3):364-70.

10. Europe, W.H.O.R.o.f. Childood obesity surveillance in the WHO European Region. 2015 Available from: http://www.euro.who.int/en/health-topics/ noncommunicable-diseases/obesity/publications/pre-2009/fact-sheet-5childhood-obesity-surveillance-in-the-who-european-region. Accessed date 10 July 2015.

11. Invitti C, Guzzaloni G, Gilardini L, Morabito F, Viberti G. Prevalence and concomitants of glucose intolerance in European obese children and adolescents. Diabetes Care. 2003;26(1):118-24.

12. Esser N, Legrand-Poels S, Piette J, Scheen AJ, Paquot N. Inflammation as a link between obesity, metabolic syndrome and type 2 diabetes. Diabetes Res Clin Pract. 2014;105(2):141-50.

13. Cook S, Weitzman M, Auinger $P$, Nguyen M, Dietz WH. Prevalence of a metabolic syndrome phenotype in adolescents: findings from the third National Health and Nutrition Examination Survey, 1988-1994. Arch Pediatr Adolesc Med. 2003;157(8):821-7.

14. Creely SJ, McTernan PG, Kusminski CM, Fisher fM, Da Silva NF, Khanolkar, et al. Lipopolysaccharide activates an innate immune system response in human adipose tissue in obesity and type 2 diabetes. Am J Physiol Endocrinol Metab. 2007;292(3):E740-7.

15. Piya MK, Harte AL, McTernan PG. Metabolic endotoxaemia: is it more than just a gut feeling? Curr Opin Lipidol. 2013;24(1):78-85.

16. Baker AR, Harte AL, Howell N, Pritlove DC, Ranasinghe AM, da Silva NF, et al. Epicardial adipose tissue as a source of nuclear factor-kappaB and c-Jun Nterminal kinase mediated inflammation in patients with coronary artery disease. J Clin Endocrinol Metab. 2009;94(1):261-7.

17. Dixon AN, Valsamakis G, Hanif MW, Field A, Boutsiadis A, Harte A, et al Effect of the orlistat on serum endotoxin lipopolysaccharide and adipocytokines in South Asian individuals with impaired glucose tolerance. Int J Clin Pract. 2008;62(7):1124-9.

18. Harte AL, Varma MC, Tripathi G, McGee KC, Al-Daghri NM, Al-Attas OS, et al. High fat intake leads to acute postprandial exposure to circulating endotoxin in type 2 diabetic subjects. Diabetes Care. 2012;35(2):375-82.

19. Miller MA, McTernan PG, Harte AL, Silva NF, Strazzullo P, Alberti KG, et al. Ethnic and sex differences in circulating endotoxin levels: A novel marker of atherosclerotic and cardiovascular risk in a British multi-ethnic population. Atherosclerosis. 2009;203(2):494-502.

20. Li J, Ma H, Na L, Jiang S, Lv L, Li G, et al. Increased hemoglobin a1c threshold for prediabetes remarkably improving the agreement between a1c and oral glucose tolerance test criteria in obese population. J Clin Endocrinol Metab. 2015;100(5):1997-2005.

21. Harte AL, da Silva NF, Creely SJ, McGee KC, Billyard T, Youssef-Elabd EM, et al. Elevated endotoxin levels in non-alcoholic fatty liver disease. J Inflamm (Lond). 2010;7:15.

22. Koning LD. Associations of total and abdominal adiposity with risk marker patterns in children at high-risk for cardiovascular disease. BMC Obesity. 2015;2(15):1-7

23. Sowers JR. Obesity as a cardiovascular risk factor. Am J Med. 2003;115(Suppl 8A):37S-41.

24. Lovren $\mathrm{F}$, Teoh $\mathrm{H}$, Verma S. Obesity and atherosclerosis: mechanistic insights. Can J Cardiol. 2015;31(2):177-83.

25. Cacciari E, Milani S, Balsamo A, Dammacco F, De Luca F, Chiarelli F, et al. Italian cross-sectional growth charts for height, weight and BMI (6-20 y). Eur J Clin Nutr. 2002;56(2):171-80.
26. Nathan DM, Davidson MB, DeFronzo RA, Heine RJ, Henry RR, Pratley R, et al. Imparied fasting glucose and imparied glucose tolerance. American Diabetes Association. 2007;30(3):753-7.

27. Matthews DR, Hosker JP, Rudenski AS, Naylor BA, Treacher DF, Turner RC. Homeostasis model assessment: insulin resistance and beta-cell function from fasting plasma glucose and insulin concentrations in man. Diabetologia. 1985;28(7):412-9.

28. Al-Attas OS, Al-Daghri N, Bamakhramah A, Shaun Sabico S, McTernan P, Huang $T$. Telomere length in relation to insulin resistance, inflammation and obesity among Arab youth. Acta Paediatr. 2010;99(6):896-9.

29. Chang CJ, Jian DY, Lin MW, Zhao JZ, Ho LT, Juan CC. Evidence in obese children: contribution of hyperlipidemia, obesity-inflammation, and insulin sensitivity. PLoS One. 2015;10(5), e0125935.

30. Gilardini L, McTernan PG, Girola A, da Silva NF, Alberti L, Kumar S, et al. Adiponectin is a candidate marker of metabolic syndrome in obese children and adolescents. Atherosclerosis. 2006;189(2):401-7.

31. Kheirandish-Gozal L, Peris E, Wang Y, Tamae Kakazu M, Khalyfa A, Carreras A, et al. Lipopolysaccharide-binding protein plasma levels in children: effects of obstructive sleep apnea and obesity. J Clin Endocrinol Metab. 2014;99(2): 656-63.

32. Smit LA, Heederik D, Doekes G, Krop EJ, Rijkers GT, Wouters IM. Ex vivo cytokine release reflects sensitivity to occupational endotoxin exposure. Eur Respir J. 2009;34(4):795-802.

33. Temple SE, Pham K, Glendenning P, Phillips M, Waterer GW. Endotoxin induced TNF and IL-10 mRNA production is higher in male than female donors: correlation with elevated expression of TLR4. Cell Immunol. 2008; 251(2):69-71.

34. Bhatia A, Sekhon HK, Kaur G. Sex hormones and immune dimorphism. ScientificWorldJournal. 2014;2014:159150.

35. Brown K, DeCoffe D, Molcan E, Gibson DL. Diet-induced dysbiosis of the intestinal microbiota and the effects on immunity and disease. Nutrients, 2012:4(8):1095-119. doi:10.3390/nu4081095.

36. Pussinen PJ, Havulinna AS, Lehto M, Sundvall J, Salomaa V. Endotoxemia is associated with an increased risk of incident diabetes. Diabetes Care. 2011; 34(2):392-7.

37. Nadeau KJ, Maahs DM, Daniels SR, Eckel RH. Childhood obesity and cardiovascular disease: links and prevention strategies. Nat Rev Cardiol. 2011;8(9):513-25.

38. Sypniewska G. Laboratory assessment of cardiometabolic risk in overweight and obese children. Clin Biochem. 2015;48(6):370-6.

39. Vael C, Desager $K$. The importance of the development of the intestinal microbiota in infancy. Curr Opin Pediatr. 2009;21(6):794-800.

40. Assimakopoulos SF, Tsamandas AC, Tsiaoussis GI, Karatza E, Zisimopoulos D, Maroulis I. Intestinal mucosal proliferation, apoptosis and oxidative stress in patients with liver cirrhosis. Ann Hepatol. 2013;12(2):301-7.

41. Schwander F, Kopf-Bolanz KA, Buri C, Portmann R, Egger L, Chollet M, et al. A dose-response strategy reveals differences between normal-weight and obese men in their metabolic and inflammatory responses to a high-fat meal. J Nutr. 2014;144(10):1517-23.

42. Schmid A, Petry N, Walther B, Bütikofer U, Luginbühl W, Gille D, et al. Inflammatory and metabolic responses to high-fat meals with and without dairy products in men. Br J Nutr. 2015;113(12):1853-61.

43. Deopurkar R, Ghanim H, Friedman J, Abuaysheh S, Sia CL, Mohanty P, et al. Differential effects of cream, glucose, and orange juice on inflammation, endotoxin, and the expression of Toll-like receptor-4 and suppressor of cytokine signaling-3. Diabetes Care. 2010;33(5):991-7.

44. Mischke M, Plosch T. More than just a gut instinct-the potential interplay between a baby's nutrition, its gut microbiome, and the epigenome. Am J Physiol Regul Integr Comp Physiol. 2013;304(12):R1065-9.

45. Kellow NJ, Coughlan MT, Reid CM. Metabolic benefits of dietary prebiotics in human subjects: a systematic review of randomised controlled trials. Br J Nutr. 2014;111(7):1147-61.

46. Lira FS, Rosa JC, Pimentel GD, Souza HA, Caperuto EC, Carnevali L, et al. Endotoxin levels correlate positively with a sedentary lifestyle and negatively with highly trained subjects. Lipids Health Dis. 2010;9:82.

47. Cote AT, Harris KC, Panagiotopoulos C, Sandor GG, Devlin AM. Childhood obesity and cardiovascular dysfunction. J Am Coll Cardiol. 2013;62(15):1309-19.

48. Ramji DP, Davies TS. Cytokines in atherosclerosis: Key players in all stages of disease and promising therapeutic targets. Cytokine Growth Factor Rev. 2015;26(6):673-85. doi:10.1016/j.cytogfr.2015.04.003. 
49. Skurk T, Hauner H. Obesity and impaired fibrinolysis: role of adipose production of plasminogen activator inhibitor-1. Int J Obes Relat Metab Disord. 2004;28(11):1357-64.

50. de Koning L, Denhoff E, Kellogg MD, de Ferranti SD. Associations of total and abdominal adiposity with risk marker patterns in children at high-risk for cardiovascular disease. BMC Obes. 2015;2:15.

51. Perkins JM, Joy NG, Tate DB, Davis SN. Acute effects of hyperinsulinemia and hyperglycemia on vascular inflammatory biomarkers and endothelial function in overweight and obese humans. Am J Physiol Endocrinol Metab. 2015;309(2):E168-76.

52. Hao XQ, Zhang HG, Yuan ZB, Yang DL, Hao LY, Li XH. Prenatal exposure to lipopolysaccharide alters the intrarenal renin-angiotensin system and renal damage in offspring rats. Hypertens Res. 2010;33(1):76-82.

53. Sordi R, Chiazza F, Patel NS, Doyle RA, Collino M, Thiemermann C.

'Preconditioning' with low dose lipopolysaccharide aggravates the organ injury / dysfunction caused by hemorrhagic shock in rats. PLoS One. 2015; 10(4), e0122096.

54. Armstrong KR, Cote AT, Devlin AM, Harris KC. Childhood obesity, arterial stiffness, and prevalence and treatment of hypertension. Curr Treat Options Cardiovasc Med. 2014;16(11):339.

55. Cote AT, Phillips AA, Harris KC, Sandor GG, Panagiotopoulos C, Devlin AM. Obesity and arterial stiffness in children: systematic review and metaanalysis. Arterioscler Thromb Vasc Biol. 2015;35(4):1038-44.

56. Prasad DS, Kabir Z, Dash AK, Das BC. Childhood cardiovascular risk factors in South Asians: A cause of concern for adult cardiovascular disease epidemic. Ann Pediatr Cardiol. 2011:4(2):166-71.

57. Thompson DR, Obarzanek E, Franko DL, Barton BA, Morrison J, Biro FM, et al. Childhood overweight and cardiovascular disease risk factors: the National Heart, Lung, and Blood Institute Growth and Health Study. J Pediatr. 2007; 150(1):18-25.

\section{Submit your next manuscript to BioMed Central and we will help you at every step:}

- We accept pre-submission inquiries

- Our selector tool helps you to find the most relevant journal

- We provide round the clock customer support

- Convenient online submission

- Thorough peer review

- Inclusion in PubMed and all major indexing services

- Maximum visibility for your research

Submit your manuscript at www.biomedcentral.com/submit

C Biomed Central 